$\mathrm{A} \int_{\text {ass }} \mathrm{H}$

Article history :

Received : 30.12.2013

Revised : 17.03.2015

Accepted : 03.04.2015

Members of the Research Forum

Associated Authors:

${ }^{1}$ Horticultural College and Research

Institute for Women, TRICHY (T.N.)

INDIA
Author for correspondence :

S. KARTHIKEYAN

Horticultural Research Station,

OOTY (T.N.) INDIA

Email : hortikarthik@gmail.com
THEASIAN JOURNALOF HORTICULTURE

Volume 10 | Issue 1 | June, 2015 | 17-25

Visit us -www.researchjournal.co.in
RESEARCH PAPER

DOI : 10.15740/HAS/TAJH/10.1/17-25

\title{
Optimization of growing media consortia for carnation
}

\section{S. KARTHIKEYAN AND M. JAWAHARLAL ${ }^{1}$}

ABSTRACT : Carnation cultivation is being carried out under protected environmental conditions in the hilly regions of Tamil Nadu. Farmyard manure, vermicompost, cocopeat constituted the media components in the consortium. The components were added based on the ratio of carbon-nitrogen level, as two levels with $20 \mathrm{~kg}$ and $30 \mathrm{~kg}$ of consortia for $1 \mathrm{sq} . \mathrm{m}$ of area. The media consortia components were added as per the treatment schedules after bed preparation. The biofertilizers Azospirillum, phosphobacteria, VAM and biocontrol agents Trichoderma viridae, Pseudomonas fluorescens were added each @ $20 \mathrm{~g} / \mathrm{m}^{2}$ at bimonthly intervals except control. The beds added with consortia at the ratio of 10:1:1 (30 kg of consortia) with $25 \mathrm{~kg}$ of farmyard manure, $2.5 \mathrm{~kg}$ of vermicompost, $2.5 \mathrm{~kg}$ of cocopeat with biofertilizers Azospirillum, phosphobacteria, VAM and biocontrol agents Trichoderma viridae, Pseudomonas fluorescens@20 g/ $/ \mathrm{m}^{2}$ at bimonthly intervals proved best in terms of yield and quality when compared to control. Yield of carnation flowers increased with $249.48,352.80,201.60 \mathrm{flowers} / \mathrm{m}^{2}$ over control with $180.00,234.00,180.00$ flowers $/ \mathrm{m}^{2}$ during $\mathrm{I}^{\mathrm{st}}, \mathrm{II}^{\text {nd }}$ and $\mathrm{III}^{\mathrm{rd}}$ flush of flowering and stalk length with $77.3073 .20,71.50 \mathrm{~cm}$ over control with $60.00,58.50,54.00 \mathrm{~cm}$ during $\mathrm{I}^{\mathrm{st}}$, $\mathrm{II}^{\mathrm{nd}}$ and III $^{\text {rd }}$ flush of flowering. The media consortia helps in retaining the soil compactness with respect to soil moisture, aeration porosity and the plant growth promoting organisms helps in mobilizing the nutrients and crop stand till the cropping period.

KEY WORDS : Carnation, Growing media consortia, Biofertilizers, Biocontrol agents

HOW TO CITE THIS ARTICLE : Karthikeyan, S. and Jawaharlal, M. (2015). Optimization of growing media consortia for carnation. Asian J. Hort., 10(1) : 17-25. 